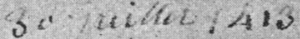

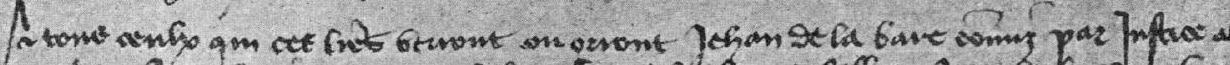

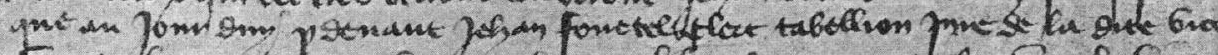

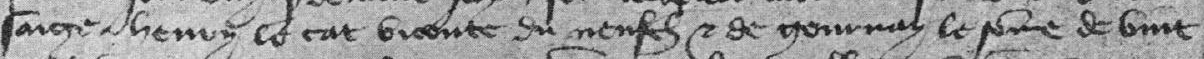

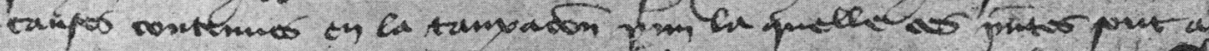

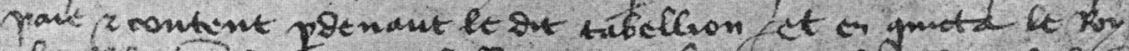

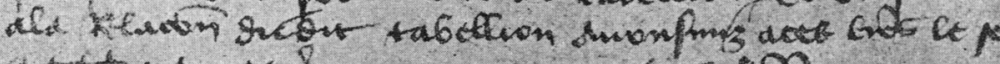
if

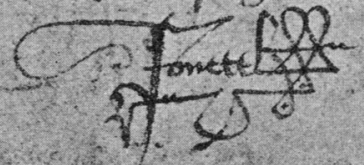

\section{A Norman French Quittance dated 1413}

A fifteenth century quittance, the oldest business document so far acquired by the Society, has come recently from Professor David Eugene Smith of Columbia University. Professor Smith is himself an enthusiastic collector, particularly in the line of the history of mathematics, and early Arabian literature on astronomy and mathematics. (His collection, by the way, includes a pair of loaded dice dug up in ancient Babylon!) Professor Smith expressed much interest and sympathy with the aims of the new-born Business Historical Society, and has favored us with two gifts one, a veritable "indenture," that is, a deed whose top has been cut in an indented manner. His second gift, shown herewith, is the quittance dated 1413, transcribed into Norman French and translated into English.

\section{TRANSCRIPTION}

A tous ceulx qui ces lettres verront ou orront Jehan de la Bare commiz par Justice ala garde du seel des obligacions de la viconte du neufchastel Salut. Savoir faisons que au jour duy pardevant Jehan Fovetel clerc tabellion jure de la dite viconte fu present Jehan de la Mote qui congnut avoir eu et receu de honourable homme et saige Henry le cat viconte du neufchastel et de Gournay le somme de vint souls tournois qui tauxez lui ont este par monsieur 


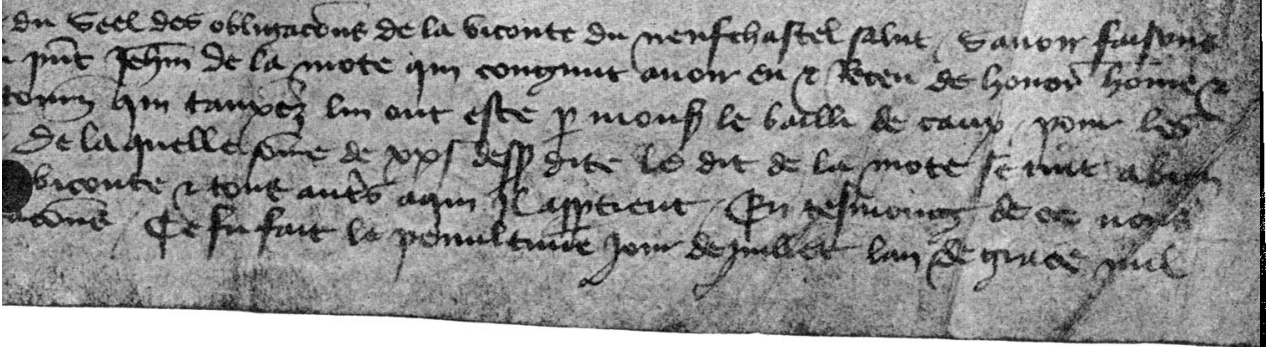

le bailli de Caux pour les causes contenues en la tauxacion parmi la quelle ces presentes sont annex. De la quelle somme de $\mathrm{xx} s$ dessus dite le dit de la Mote se tint abien paie et content pardevant le dit tabellion et en quieta le Roy messieur le dit viconte et tous autres a qui il appartient. En tesmoing de ce nous ala relacion dudit tabellion anrusunz (?) aces lettres le seel des dites obligacions. $\mathrm{Ce}$ fu fait le penultime jour de juillet lan de grace mil CCCC et treize.

Fovetel

\section{TRANSLATION}

To all those who shall see or hear these letters, John de la Bare, entrusted by justice with the custody of the seal of bonds in the viscounty of Neufchatel, sends greeting. We give you to understand that on the proper day before John Fovetel, clerk and notary sworn of the said viscounty, there was present John de la Mote who confessed that he had received from the honourable and worthy Henry le Cat(sic.), viscount of Neufchatel and Gournay, the sum of twenty shillings Tournois taxed against him by Monsieur the Bailiff of Cauz for reasons contained in the taxation to which these presents are annexed. Of which sum of twenty shillings aforesaid the said de la Mote holds himself fully paid and contented before the said notary, and acquits thereof the King, Monsieur the viscount aforesaid and all others concerned. In witness whereof, and on the information of the said notary, we have added to these letters the said seal of bonds. Made the penultimate day of July, the year of grace $1_{4} I_{3}$. 